Pamiętnik Literacki 2021, 1, s. 111-118

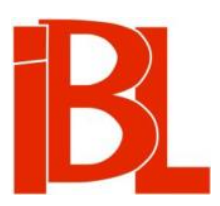

\title{
Pawel Huelle - czytany z Walterem Benjaminem
}

\author{
Marion Brandt
}


Pamiętnik Literacki CXII, 2021, z. 1, PL ISSN 0031-0514

DOI: $10.18318 / \mathrm{pl} .2021 .1 .7$

MARION BRANDT Uniwersytet Gdański

\section{PAWEŁ HUELLE - CZYTANY Z WALTEREM BENJAMINEM*}

Protagonista debiutanckiej powieści Weiser Dawidek Pawła Huellego ${ }^{1}$ to uosobienie tajemnicy i nierozwiązywalnej zagadki - nie tylko dla narratora. Również interpretatorzy tego tekstu nie są zgodni, gdy idzie o odczytywanie tytułowej postaci; świadczą o tym różne przypisywane jej znaczenia, które nierzadko trudno ze sobą pogodzić.

Prawdopodobnie najbardziej rozpowszechnione i najtrafniejsze interpretacje znajdziemy w pracach Przemysława Czaplińskiego. Poznański literaturoznawca umieścił powieść w nurcie nostalgii, który według niego charakteryzuje polską literaturę lat osiemdziesiątych i dziewięćdziesiątych XX wieku². Rzeczywiście, jako centralny topos powieści Huellego można postrzegać wspominanie utraty, i to na kilku płaszczyznach: dorosły narrator pamięta Dawida Weisera, towarzysza cudownych zabaw dzieciństwa, który zniknął w tajemniczy sposób. Poprzez wspomnienia o Weiserze powraca nie tylko do swojego dzieciństwa, ale również do Gdańska lat pięćdziesiątych. Sam Weiser również jest figura pamięci. Opowiada dzieciom o historii niemieckiego Gdańska, a jego własna, mało znana biografia, wpisuje się w historię Shoah.

Aby omówić znaczenie tych wspomnień w powieści Huellego, kilku interpretatorów posługuje się pojęciem tożsamości: poprzez pamięć o Dawidzie Weiserze narrator poszukuje świadomości siebie. Według François Rosseta narrator pyta o Weisera, chcąc dowiedzieć się czegoś o sobie ${ }^{3}$, Czapliński zaś traktuje powieść Huellego jako jeden $z$ tych utworów literackich, „dla których zagadnieniem podstawowym była kwestia tożsamości" ${ }^{4}$. Poszukiwanie własnej tożsamości postrzegane jest ponadto jako próba odnalezienia się Polaka w Gdańsku, w mieście, które

* Artykuł stanowi nieco zmienioną i rozszerzoną wersję niemieckiego artykułu Pawet Huelle gelesen mit Walter Benjamin, który ukazał się w zb.: In officio amicitiae: Andreas Lawaty dem Grenzgänger und Freund zum 65. Geburtstag. Hrsg. K. Ru chniewicz, S. Troebst, M. Zybura. Dresden 2018. Za redakcje polskiego tłumaczenia dziękuję pani prof. UAM dr hab. Mał g o r za ci i $Z \mathrm{Zdu}-$ niak-Wiktorowicz.

$1 \quad$ P. Huelle, Weiser Dawidek. Gdańsk 1987.

2 P. Czapliński, Wzniosłe tęsknoty. Nostalgie $w$ prozie lat dziewięćdziesiatych. Kraków 2001, s. 166, 222. - P. Czapliński, P. Śliwiński, Literatura polska 1976-1998. Przewodnik po prozie i poezji. Kraków 2002, s. 200-201.

3 F. Ros s et, Dawidek, der Weise. „Zeszyty Literackie” 1988, nr 2, s. 123-126.

4 Czapliński, Śliwiński, op. cit., s. 258. 
w pewnym stopniu było dla niego kulturowo obce. Poprzez pytanie „kim jest Weiser” narrator zastanawia się nad swoją tożsamością - polskiego gdańszczanina ${ }^{5}$.

Jan Błoński z kolei czyta powieść również jako część nurtu literackiego, który charakteryzuje „szukanie czy odtwarzanie jednostkowej i zbiorowej tożsamości”, ale interpretuje ten utwór w innym kontekście:

Poddana pustoszącej presji reżimu, który człowieka upraszczał, ujednolicał, można by powiedzieć nihilizował... literatura szukała ratunku w korzeniach, w historii, w przeszłości. Stąd moda na Kresy, Habsburgów, Żydów... na to, co inne, własne ${ }^{6}$.

Z tej perspektywy w postać Dawida Weisera można wpisać nadzieję na inne życie, bohater ten może uosabiać wartości i ideały, których brakowało w socjalistycznej Polsce. Błoński zadał nawet pytanie, czy Weisera da się odczytać jako parabolę polityczną:

Czy on nie jest przypadkiem Solidarność, ten cały Weiser? Pomyślcie, gdzie, kiedy, skąd się wziął, czego chciał i kogo nie lubił... I jak się pod ziemię zapadł, kto go szuka? Nie, nie, na pewno tak nie jest, nie rób Pan z ludzi wariatów, panie Błoński! Pewnie że nie jest. Ale przecież trudno nie dosłyszeć rozmaitych drażliwych rezonansów tej powieści... ${ }^{7}$

Weiser jako uosobienie kulturowego Innego staje się w powieści znakiem obietnicy szczęśliwego życia. Przemawia za tym także pewien pre-tekst (przed-tekst, intertekst) Weisera Dawidka, a mianowicie utwór Mój przyjaciel Meaulnes Henriego Alaina-Fourniera ${ }^{8}$, który to utwór wskutek tego, że analizując inspiracje powieści Huellego, przywoływano głównie takie dzieła Güntera Grassa, jak Kot i mysz oraz Blaszany bębenek, zszedł $\mathrm{w}$ badaniach na nieco dalszy plan. Wydaje mi się on jednak istotny, ponieważ Alain-Fournier opisuje w jego pierwszej części spotkanie w szkole młodych ludzi z nowym uczniem, który staje się dla nich uosobieniem niezwykłego życia. Ze zbliżona sytuacją mamy do czynienia w powieści Huellego, gdzie pierwszoosobowy narrator, opowiadający później o owym wyjątkowym spotkaniu $z$ Weiserem, ulega wielkiej fascynacji tajemniczym przybyszem.

Analizując utwór Huellego, Lothar Quinkenstein zwrócił uwagę na związek między pamięcią a myśleniem o przyszłości. Pisał, że w końcowej sekwencji powieści „daremne poszukiwanie Weisera przedłuża się jak niekończąca się spirala”, wyobrażona jako „ciagłe, bezsilne powtórzenie” ${ }^{9}$. Nadzieja na powrót Weisera nie zostanie spełniona, lecz będzie przesuwana w nieokreślona przyszłość, pozostanie już poza narracją.

Z perspektywy narratora Weiser przyjmuje cechy oczekiwanego zbawiciela. Narrator przypomina sobie sen, w którym, niczym w scenie apokaliptycznej, para-

5 Ros s et, op. cit., s. 125.

6 Czarna dziura lat osiemdziesiatych. O literaturze ostatniej dekady dyskutują: Jan Błoński, Tadeusz Nyczek, Jerzy Jarzębski, Marian Stala oraz - ze strony redakcji „TP” - Jerzy Pilch. „Tygodnik Powszechny" 1990, nr 13, z 1 IV, s. 4.

7 J. Błoński, Duch powieści i was Stalina. W: Wszystko, co literackie. Pisma wybrane. Wybór, oprac. J. Jarzębski. T. 1. Kraków 2001, s. 373. (Pierwodruk: „Tygodnik Powszechny” 1987, nr 44).

8 Zob. T. Komendant, Sny na jawie. „Twórczość” 1992, nr 1, s. 103.

$9 \quad$ L. $Q$ u in k e n s t e in, Entzifferte Geschichte. Bild und Funktion der Stadt bei Günter Grass, Bolesław Fac, Stefan Chwin, Paweł Huelle und Jerzy Limon. Poznań 1998 (nieopublikowana praca doktorska), s. 120. 
frazującej wizję proroka Daniela ${ }^{10}$, Weiser ukazał mu się jako Mesjasz. Błoński nawiązuje do tej wizji w stwierdzeniu: „Najwłaściwsze jest [...] dla Weisera odniesienie mesjańskie" ${ }^{11}$. Ta perspektywa interpretacyjna poparta zostaje elementami chrystologicznymi, takimi jak imiona chłopców przypominające apostołów (Szymon, Piotr i prawdopodobnie Paweł) czy piknik w przeddzień zniknięcia Weisera. Analiza tychże wątków doprowadziła Krzysztofa Gajewskiego w artykule poświęconym utworowi Huellego do konkluzji: „W powieści Weiser Dawidek, jej bohater tytułowy, stanowi figurę Chrystusa"12. Także Marek Zaleski odczytuje postać Weisera jako „figurę sacrum”, podkreśla jednak, że „to sacrum niekoniecznie z tradycji chrześcijańskiej czy judaistycznej”, lecz raczej „sacrum pierwotne” 13 .

Na tle tych tez interpretacyjnych ważne wydaje mi się pytanie o to, w jaki sposób można przy lekturze Weisera Dawidka zbudować most myślowy prowadzący od pamięci historii jako przeżycia straty (strat) bądź jako traumy do obietnicy szczęśliwej przyszłości, a nawet do mesjanizmu, zatem most między doświadczeniem historycznym i religijnym.

Taką możliwość dają nam tezy Waltera Benjamina zawarte w jego pracy $O$ pojęciu historii. Ten ostatni tekst myśliciela, który pozostał fragmentem, szkicem, a uważany jest za jego „filozoficzno-polityczny testament” ${ }^{14}$, został napisany zimą 1939/40 i stanowi reakcję filozofa nie tylko na wybuch drugiej wojny światowej, ale także na „szok wywołany paktem Hitler-Stalin” ${ }^{15}$. W swych historyczno-filozoficznych tezach Benjamin spogląda więc na historię z perspektywy porażki i krytykuje wywodzącą się z oświecenia liniową koncepcje postępu, która charakteryzuje również myśl marksistowską, materializm historyczny i programy polityczne ruchu robotniczego. Przeciwstawia tej koncepcji figurę myślową, za której pomocą da się uchwycić przełamanie kontinuum historycznego, czyli momentu, kiedy, według Benjamina, możliwa jest rewolucyjna zmiana i inna/nowa przyszłość. Ideę postępu charakteryzuje on za pomoca słynnej interpretacji grafiki Paula Klee Angelus Novus jako „anioła historii”:

Twarz zwrócił ku przeszłości. Gdzie n a m ukazuje się łańcuch wydarzeń, on widzi jedną wielką katastrofę, która nieustannie piętrzy gruzy i ciska mu je pod nogi. Chciałby może się zatrzymać, pobudzić umarłych i złączyć to, co rozbite. Lecz od raju wieje wicher, który zaplątał mu się w skrzydła i jest tak potężny, że anioł nie może już ich złożyć. Wicher ten gna go niepowstrzymanie w przyszłość, do której zwrócony jest plecami, podczas gdy przed nim po samo niebo rosną zwaliska gruzów. To, co my nazywamy postępem, to ten właśnie wicher ${ }^{16}$.

Zob. M. P a r zy c h, „Weiser Dawidek”. Klucz do twórczości Pawła Huellego. Studia. Białystok 2016, s. 89.

Błońs ki, op. cit., s. 371-372.

K. Gajewski, „Weiser Dawidek” jako opis doświadczenia religijnego. „Teksty Drugie” 2004, nr 1/2, s. 299.

M. Zale sk i, Czarna dziura. W: Formy pamięci. Gdańsk 2004, s. 97.

M. Brod er s e n, Walter Benjamin. Frankfurt am Main 2005, s. 129.

G. S c h o l e m, Walter Benjamin und sein Engel. W zb.: Zur Aktualität Walter Benjamins. Aus Anlaß des 80. Geburtstags von Walter Benjamin. Hrsg. S. Un s eld. Frankfurt am Main 1972, s. 129. Zob. też K. Sa u erland, Od Diltheya do Adorna. Studia z estetyki niemieckiej. Warszawa 1986, s. $140-141$.

W. B e nj a min, O pojęciu historii. W: Konstelacje. Wybór tekstów. Wstęp A. Li p s zy c. Kraków 2012, s. 316 (przel. A. Lip szy c). 
Przeszłość rysuje się tu Benjaminowi jako katastrofa, jako nagromadzenie gruzów, pozostałości zniszczeń, przemocy i wojen. Myślenie historyczne ukierunkowane na postęp łączy się z utożsamieniem się ze zwycięzcami, władcami, natomiast opowieści pokonanych, przegranych sa zapomniane, wyparte, odesłane w niebyt. Benjaminowi chodzi jednak właśnie o tę stłumioną przeszłość. „Materialista historyczny", za którego sam się uważa, nie może widzieć teraźniejszości wyłącznie jako części kontinuum historii, jako (pustego, do wypełnienia przez nas) okresu przejściowego między wczoraj a lepszym jutrem. Teraźniejsza chwila musi reprezentować stłumioną przeszłość, „zapamiętać” ją. „Anioł historii” nie jest w stanie zatrzymać się w czasie, aby „pobudzić umarłych i złączyć to, co rozbite”. Benjamin tworzy inny model, pozwalający myśleć o teraźniejszości, w której kontinuum historii zostaje przełamane. Filozof opiera się przy tym na mesjańskiej idei cechującej judaizm, dla Żydów bowiem „każda [...] sekunda była mała furtką, przez którą mógł wkroczyć Mesjasz”17. Nie „anioł historii”, ale Mesjasz może „pobudzić umarłych i złączyć to, co rozbite”. Moment, w którym przywróci w teraźniejszość to, co zostało wcześniej wyparte, Benjamin opisuje jako moment „mesjańskiego powstrzymania biegu wydarzeń" ${ }^{18}$. Sam proces zapamiętania uciemiężonej przeszłości, domagania się pamięci o przegranych Benjamin ujmuje w słowie „Eingedenken”, które według Adama Lipszyca można tłumaczyć jako „ruch pomnienia czy upomnienia się" ${ }^{19}$. Jak podkreśla Stefano Marchesoni, w rozumieniu Benjamina „Eingedenken” „nie polega na przypomnieniu sobie treści pamięci, lecz na niezamierzonym i niespodziewanym wtargnięciu w teraźniejszość potencjału drzemiącego w przeszłości, tzn. ostatecznie na żą d a ni u / w e z w a n i u wskazującym na przyszłość" ${ }^{20}$. Moment pamięci i przerwania kontinuum historycznego jest jednocześnie momentem rewolucyjnym. Benjamin mówi o „rewolucyjnej szansie w walce na rzecz uciśnionej przeszłości”, o tym, że my - jak uczy „tradycja uciśnionych” żyjemy w sytuacji, którą można nazwać stanem wyjątkowym i że naszym zadaniem jest „wprowadzenie rzeczywistego stanu wyjatkowego" ${ }^{21}$.

Choć refleksja historyczno-materialistyczna zapewne nie była bliska Huellemu, istnieją uderzające podobieństwa między myślą Benjamina o czasie zastoju jako momencie mesjanistycznym, w którym wraca wyparta przeszłość nosząca ze sobą potencjał zbawczy, a powieścią Weiser Dawidek. Spotkania dzieci z Weiserem przypadają na jedno lato, kiedy czas zwykły zatrzymuje się. Śmierć ryb w Zatoce Gdańskiej powoduje, że dzieci nie mogą spędzać wakacji tak jak zawsze nad morzem i ze swoimi zabawami przenoszą się na zaniedbany niemiecki cmentarz, miejsce o charakterze transgranicznym, gdzie przekraczają próg między teraźniejszością a przeszłością. Czas zastoju przybiera wymiar apokaliptyczny. Ten wątek podkreślają wypowiedzi duchownych, interpretujących klęskę żywiołowa jako karę za grzeszne

Ibidem, s. 323.

Ibidem, s. 321-322.

M. Ole si k, Lipszyc: Celan - język i Zagłada. Rozmowa z A. Lipszycem. „Dziennik Opinii. Krytyka Polityczna” 2013, nr z 18 XI. Na stronie: http://www.krytykapolityczna.pl/artykuly/kultura/20131117/lipszyc-celan-jezyk-i-zaglada (data dostępu: 5 V 2020).

S. M a r c h e s o n i, Walter Benjamins Konzept des Eingedenkens. Über Genese und Semantik einer Denkfigur. Berlin 2016, s. 294.

B en j a min, op. cit., s. 322, 315. 
życie, a „Żółtoskrzydlaty”, uciekinier ze szpitala psychiatrycznego, publicznie głosi kazania o bliskim Sądzie Ostatecznym. Weiser ujawnia się w tej sytuacji jako uosobienie tłumionej przeszłości i jej mesjańskiego wymiaru.

Motyw wstrzymanego czasu można odnaleźć nie tylko w fabule powieści, ale także na poziomie narracji. Czytelnik nie dowiaduje się o współczesności narratora prawie niczego, wiemy jedynie, że jest on skupiony na poszukiwaniu prawdy o Weiserze, wypełniony pamięcią i tęsknota za jego powrotem. Czas narracji można uściślić jako początek lat osiemdziesiątych i tym samym kojarzyć z rzeczywistym stanem wyjątkowym w Polsce: stanem wojennym lat 1981-1983. Ponieważ jest to także czas, w którym powieść została napisana ${ }^{22}$, wolno nawet zaryzykować stwierdzenie, że Huelle opowieścią o apokaliptycznym lecie przeciwstawił realnemu stanowi wojennemu, rozbiciu Solidarności - inny stan: stan zastoju, w którym stłumiony Nieobecny przyjmuje wymiar mesjański. Tak jak Benjamin zarysował swoje tezy historyczno-filozoficzne w obliczu politycznej porażki, również Huelle napisał Weisera Dawidka w sytuacji przegranej. Późniejsze wspomnienie autora o tym, iż zdjęcie Chrisa Niedenthala z 14 grudnia 1981, przedstawiające warszawskie kino „Moskwa” z napisem „Czas Apokalipsy” (tytułem filmu F. F. Coppoli), stało się "jedną z pierwszych - niezwykle popularnych - ikon stanu wojennego" 23 , dowodzi, że brutalne zakończenie procesu demokratyzacji, rozpoczętego w sierpniu 1980, postrzegano $\mathrm{w}$ kategoriach apokalipsy. O przypisywaniu zaginionemu Weiserowi roli zbawiciela mówi nie tylko sen, w którym bohater ukazuje się jako Mesjasz walczacy z apokaliptycznymi bestiami. Strzelanie dzieci do makiet z podobiznami Hitlera, Stalina i znienawidzonego nauczyciela przyrody M-skiego sygnalizuje ponadto związany z pojawieniem się Weisera element oporu przeciwko totalitaryzmowi i opresyjnej władzy.

Również w innych tekstach Huellego do spotkań narratora $\mathrm{z}$ obcą kulturowo przeszłością dochodzi w momentach, gdy przerywany jest regularny bieg czasu. Takie otwierające się na historię okna czasowe można znaleźć m.in. w opowiadaniach Stół (droga w historię zaczyna się od problemu: stól, nabyty kiedyś od Niemca, nie nadaje się już do użytku i trzeba kupić nowy) oraz Winniczki, kałuże, deszcz (tutaj okno czasowe pojawia się wraz ze zwolnieniem z pracy ojca narratora). $Z$ kolei w Przeprowadzce opóźnia się transport mebli do nowego mieszkania i rodzina narratora niespodziewanie musi zostać dłużej w pokoju wynajętym po wojnie w dawnym niemieckim domu. Narrator, 4- lub 5-letni chłopiec, w tej sytuacji zastoju nagle znajduje w sobie odwagę: mimo zakazu matki pójdzie do byłej właścicielki domu, której gra na fortepianie fascynowała go od dawna. Podobnie jak w Weiserze Dawidku przeszłość staje się w tym opowiadaniu znakiem obietnicy szczęścia - niespełnionej i przez to wskazującej na czas poza narracją: wśród utworów, które niemiecka sąsiadka gra bohaterowi, brakuje właśnie jego ukochanej

22 Powieść ukazała się, co prawda, dopiero w roku 1987, Huelle zakończył ja jednak już w 1984 roku. O związkach między pierwszymi próbami pisania a doświadczeniem Solidarności i stanu wojennego zob. P. H u ell e, „Interesuje mnie zmyślenie i forma”. Rozmowa „Pulsu” z Pawtem Huelle. „Puls” 1991, nr 3, s. 40-44.

23 P. Hu elle, W cieniu Conrada. W zb.: Ksiega Janion. Oprac. Z. Majch row ski, S. Rosiek. Gdańsk 2007, s. 383. 
melodii. Pewnego wieczoru rodzice tańczyli do tej melodii, marząc o podróży poślubnej, do której nigdy nie doszło. Protagonista nazywa ów utwór „melodią czerwcowego wieczoru” i jest pewny, że to „melodia miłosna”. Od sąsiadki nie dowie się jednak, kto ją skomponował, a na koniec opowieści pomyśli: „nigdy się już tego nie dowiem" 24 .

Tak więc, podobnie jak w Weiserze Dawidku, kulturowo obca przeszłość uosabia tęsknotę za szczęściem i spełnieniem. Moim zdaniem, wrażenie, że późniejsze teksty Huellego traca magię, wynika $z$ faktu, iż spotkanie $z$ przeszłością i jego znaczenie dla bohatera-narratora nie zostaje $\mathrm{w}$ nich przedłużone $\mathrm{w}$ otwarta, nieznaną przyszłość, poza fabułę narracyjną; innymi słowy - że utwory te nie pozostawiają już pustego miejsca, które może wypełniać tęsknota za Nieobecnym. Przykład tego stanowi powieść Śpiewaj ogrody z 2014 roku. Narrator odwiedza swoją byłą niemiecką sąsiadkę Gretę Hoffmann, najpierw kilka razy w jej domu, później w domu starców, i pyta ją o przeżycia z przeszłości. Spotkania te sięgają również w przyszłość, gdyż bohater utrwala je potem w swej sztuce, a dokładniej: we własnej kompozycji („partyturze”). Jako taką kompozycję charakteryzuje wreszcie sam tekst powieści. W jej zakończeniu powie:

Tak, zacząłem pisać moją partyturę właśnie od tej sceny [...]. Rozpisałem motyw altowiolisty Foxa na kilka stron, lecz przecież nie mógł ogarnąć tej historii, płynnie przechodzić z jednego miejsca do drugiego [...]. Odłożyłem go i teraz umieszczam na końcu, choć miał być na początku ${ }^{25}$.

Katastrofy historyczne XX wieku występują w powieści Śpiewaj ogrody w dużo większym stopniu niż w Weiserze Dawidku. Utwór opowiada o czasach nazistowskich, prześladowaniach Żydów i Słowian, o śmierci w obozach koncentracyjnych, deportacjach, przymusowym wysiedleniu i utracie ojczyzny. Przeszłość ta nie nosi jednak „sekretnego wskaźnika, który odsyła ją ku zbawieniu” w rozumieniu Benjamina ${ }^{26}$. Huelle przeciwstawia jej bowiem sztukę, wrażliwość estetyczną, a także miłość i empatię. W powieści brakuje natomiast wymiaru przyszłości; obietnica szczęścia nie jest rzutowana w nieznaną przyszłość, ale spełnia się w twórczości artystycznej, w sztuce mówiącej o tym, czego nie ma. Przywołany w tytule motyw ogrodu, który zatrzymuje zaginioną przeszłość w jednym obrazie, ma tu zasadnicze znaczenie. Frazę „Śpiewaj ogrody” zawiera początek jednego z Sonetów do Orfeusza Rainera Marii Rilkego $(2,21)$ :

Śpiewaj ogrody, których nie znasz, serce moje, jak w szklane naczynia wlane ogrody, jasne, nieosiagalne ${ }^{27}$.

Tytuł ten nawiązuje równocześnie do dwóch wspomnianych w powieści ogrodów: ginącego po wojnie parku przy domu Grety Hoffmann oraz galicyjskiego, opuszczonego ogrodu babci narratora. Oba miejsca można odczytać jako obrazy przeszłości, nieosiagalnej dla bohatera-narratora, a przez to przybierającej dlań arkadyjskie

P. Hu elle, Opowiadania na czas przeprowadzki. Londyn 1991, s. 51.

P. Hu elle, Śpiewaj ogrody. Kraków 2014, s. 318.

Benj a min, op. cit., s. 312.

R. M. Rilke, Sonety do Orfeusza: pomyślane jako epitafium dla Wery Ouckama Knopp. Przekł., wstęp M. Jastru n. Kraków 1961, s. 75. 
cechy. To, co utracone, jest w nich zamknięte niczym w pięknym medalionie. W momencie, kiedy dostrzega podobieństwo babci i byłej niemieckiej sassiadki, czyli więź między obiema kobietami i ich ogrodami, narrator po raz pierwszy myśli o „własnej partyturze”, w której będzie zapisywał spotkania z Gretą.

Przedstawione przeze mnie rozważania pokazują, że „sonda” Benjaminowska może przyczynić się do głębszego zrozumienia twórczości Pawła Huellego. Pozostaje jeszcze pytanie, czy Huelle inspirował się Benjaminem. Sądzę, że jest to możliwe, ponieważ ten niemiecko-żydowski filozof był silnie obecny w „kolektywie myślowym” (Ludwik Fleck) krytycznych intelektualistów w Polsce w drugiej połowie lat siedemdziesiątych i na początku lat osiemdziesiątych XX wieku. Tezy historiozoficzne Benjamina ukazały się w 1975 roku w pierwszym polskim wydaniu jego esejów Twórca jako wytwórca, zredagowanym przez poznańskiego germanistę Huberta Orłowskiego. We wstępie do tego tomu czytamy m.in., że Benjamin nie brał pod uwage pewnych aspektów istotnych dla myśli marksistowskiej ${ }^{28}$. Odchylenia od marksizmu mogły nadać jego esejom szczególną aurę i budzić zainteresowanie, co potwierdza recenzja Adama Zagajewskiego, który określił książkę jako dzieło „marksisty z drugiej strony frontu ideologicznego”29. Leszek Kołakowski w trzeciej części swojej książki Główne nurty marksizmu, wydanej w Paryżu w latach 19761978, odnosząc się do historyczno-filozoficznych tez Benjamina, podkreślił właśnie zawartą w nich krytykę pojęcia postępu i marksistowskiej idei historii, prowadzącej do jakiegoś stanu idealnego. Pisał też o „dziurze w czasie”, przez którą wchodzi Mesjasz:

Benjamin miał silne konserwatywne poczucie trwałości przeszłości i usiłował je godzić z rewolucyjną wiarą w nieciąłość dziejów. Sam kojarzył tę ideę nieciągłości z tradycją żydowskiego mesjanizmu i wbrew marksizmowi uważał, że eschatologia czysto immanentna nie jest możliwa, że eschaton nie może zjawić się jako naturalna kontynuacja dotychczasowego potoku zdarzeń, ale musi wkroczyć przez jakąś dziurę w czasie, właśnie jak Mesjasz ${ }^{30}$.

Komentarze te, zawarte w bardzo znanym dziele Kołakowskiego, które do roku 1989 mogło być publikowane tylko na emigracji i w niezależnych wydawnictwach w Polsce, musiały czynić eseje Benjamina szczególnie atrakcyjnymi dla osób myślących krytycznie. Twórczość Benjamina była również tematem na seminarium Marii Janion na Uniwersytecie Gdańskim ${ }^{31}$, w którym uczestniczył młody Paweł Huelle. Rozmowa z Günterem Grassem w czerwcu 1981 pokazuje natomiast, że jednym z tematów, którymi interesowali się uczestnicy tego seminarium, była krytyka Heglowskiej koncepcji postępu ${ }^{32}$.

Wyjątkowy w twórczości Huellego wybór żydowskiego bohatera, z jakim mamy

Zob. J. Kmita, wstęp w: W. B enja min, Twórca jako wytwórca. Wybór H. Orłow s ki. Przeł. H. Orłowski, J. Sikorski. Poznań 1975, s. 5-10.

Cyt. za: R. Ró ża n ow s ki, Walter Benjamin po polsku-aspekty recepcji. „Zbliżenia Polska-Niemcy" 1994, nr 1, s. 23.

L. Koła k ow s k i, Główne nurty marksizmu. Powstanie - rozwój-rozkład. T. 3. Paryż 1978, s. 351. Odmieńcy. Wybór, oprac., red. M. J a ni o n, Z. M aj ch row ski. Gdańsk 1982, s. 433. - Osoby. Wybór, oprac., red. M. J a ni o n, S. Ro siek. Gdańsk 1984, s. 355, 376, 383.

Grass, Hegel i Syzyf. Dyskusja w: Günter Grass i polski Pan Kichot. Napisała i zebr. M. J a n i on. Gdańsk 1999, s. 9-10. 
do czynienia w powieści Weiser Dawidek, może również wskazywać na Benjaminowskie inspiracje gdańskiego pisarza. Kreację tej niezwykłej postaci można zatem wytłumaczyć nie tylko pamięcią o traumatycznej przeszłości, ale także nawiązaniem do mesjanistycznego myślenia opartego na religii żydowskiej.

\author{
Abstract \\ MARION BRANDT University of Gdańsk \\ ORCID: 0000-0003-0037-4419
}

\title{
PAWE⿺ HUELLE'S READING ALONGSIDE WALTER BENJAMIN
}

The author interprets the novel Weiser Dawidek (Who Was David Weiser?) by Paweł Huelle against the background of Walter Benjamin's historiosophical theses. She points out the similarities between Benjamin's thought of the time stopped at the moment when the Messiah appeared and Huelle's novel. The encounter between the narrator and Weiser occurs when the regular flow of time is interrupted, and Weiser himself can be interpreted as the incarnation of the suppressed past and its "secret index by which it is referred to redemption" (Benjamin). In the further part of the article the author compares the novel Weiser Dawidek (Who Was David Weiser?) with other Huelle's texts the action of which follows a similar pattern. 